\title{
Recovery of Phytochemicals via Electromagnetic Irradiation (Microwave-Assisted-Extraction): Betalain and Phenolic Compounds in Perspective
}

\author{
Moh Moh Zin ${ }^{1, * \mathbb{C}}$, Chukwuka Bethel Anucha ${ }^{2}$ and Szilvia Bánvölgyi ${ }^{1}$ \\ 1 Department of Food Engineering, Szent István University, Ménesi út 44, 1118 Budapest, Hungary; \\ Banvolgyi.Szilvia@etk.szie.hu \\ 2 Department of Chemistry, Karadeniz Technical University, 61080 Trabzon, Turkey; chikadoog@ktu.edu.tr \\ * Correspondence: zinlay.net.mm@gmail.com
}

Received: 4 June 2020; Accepted: 7 July 2020; Published: 12 July 2020

check for updates

\begin{abstract}
Food colorants processed via agro-industrial wastes are in demand as food waste management becomes vital not only for its health benefits but also for cost reduction through waste valorization. Huge efforts have been made to recover valuable components from food wastes and applied in various fields to prove their versatility rather than for feed ruminant usage only. Betalains and phenolics, antioxidant-rich compounds responsible for host color and so commonly used as natural colorants in food and cosmetic industries, are copiously present in several kinds of fruits and vegetables as well as their wastes. Technological innovation has brought extensive convenient ways of bioactive compounds extraction with many advantages like less use of solvents and energy in a short period of processing time in comparison with the classical solid-liquid extraction methods. Emerging technologies, particularly microwave irradiation, have been amenable to electromagnetic technology for decades. Practically, they have been deployed for functional and supplement food production. In this review, the feasibility of dielectric heating (microwave irradiation) in the extraction of betalain and phenolic compounds mostly from fruit and vegetable wastes was discussed.
\end{abstract}

Keywords: betalains; phenolic compounds; antioxidants; microwave irradiation; emerging technology; phytochemicals

\section{Introduction}

Global interest for natural food colors is on the rise, especially in Asian countries. Historically, food ingredients and spices like yellow turmeric and red pepper powders are easily prone to food adulteration [1]. They play very essential roles in traditional cuisines and are valued for their therapeutic properties irrespective of their color. Current innovation and developmental trend in food processing has led to a paradigm interest in food additives and bioactive compounds with particular focus on their nutritional and organoleptic values.

Among the bioactive compounds, betalains and phenolics are the most auspicious with plenty of health benefits, making them easily compatible with food fortification and supplementation. The discovery of betanin, betanidin, and indicaxanthin derivatives following their degradation led to the assumption of their unique nature together with betaxanthin (formerly known as flavonoid) and betacyanin (regarded as nitrogenous anthocyanin) [2]. This led to them being grouped as betalains in 1968 [3]. Among the acknowledged sources of betalains, i.e., beetroot, swiss chard, dragon fruit, and prickly pear [3-6], beetroot has gained the most attention since, apart from the whole tuber, even their waste parts such as stalk [7], peel [8,9], and pomace [10,11] are rich in betalains. The ratio of color contents is decisively influenced by specie source, genetic, cultivar, or the environment of 
cultivation throughout growing, and the stages of harvesting $[4,12,13]$. Practically, one kilogram of fresh beetroot contains 300-600 $\mathrm{mg}$ of betacyanin and 320-420 $\mathrm{mg}$ of betaxanthin [14]; compared to the flesh, betalain concentration ranges from 40 to $70 \%$ higher in the peel and it also depends on genotypes [15].

As reducing agents, phenolic compounds can inhibit oxidation reaction catalyzed by enzymes and can stabilize lipid peroxidases [16]. Over 10,000 phenolic compounds exist in several kinds of fruits and vegetables, cereals, tea leaves, coffee beans, and their accumulation in the whole parts of the plant including root, stem, bark, flower, and leaf have been noticed [17]. Their extraction from various sources has been boosted by emerging technologies these days, particularly microwave radiation. Some of them are twenty cultivars of tomatoes [18], six plant species [19], four types of spices [16], four types of algae (brown macroalgae species) [20], and the rest are discussed in the next section with their proper process optimization. Balasundram and coworkers [21] reviewed phenolic compound structures found in by-products of fruit and vegetable processing. Extraction of phenolic compounds from these food products, however, remains a developing field as different techniques are continually being explored.

Compared to conventional extraction techniques, non-conventional methods are more pronounced for better quality and quantity of desired products due to advantages such as less use of solvent and lower exposure time to high temperature [22]. Specifically, major advantages of microwave treatments are the reduction in operation time and solvent consumption (critically possibility of solvent-free processing), less energy consumption as the rays are delivered directly to the matrix, as well as their ease of handling and processing [23]. As reported by Cardoso-Ugarte and coworkers [24], the same amount of betalain concentration can be achieved by microwave irradiation ten times faster than the conventional ways with betalain yield scaled up to double. However, with dielectric heating, acceleration in the chemical reaction of target compounds such as epimerization, oxidation, and polarization during microwave processing should be considered [14]. The aim of this review was to point out the versatility of microwave irradiation in the recovery of bioactive compounds focusing on phenolics and betalains from various kinds of fruits and vegetables for their improved practical application in food and beverages, pharmaceuticals, cosmetics, and other related sectors.

\section{Food Color Compounds}

Functional additives are compulsory in food processing in order to improve or maintain the existing properties of food during processing [25]. Bio-colorants have been explored from plants (flower, root, stalk, seed, fruit, peel, leaf, pomace, rhizome, and stigma), insect (cochineal), algae, bacteria, and fungi [25-27] and their existence is essential for pollination and seed disposal as insects and birds are attracted by their hues [28]. Carotenoids, phenolics, alkaloids, nitrogen-containing compounds, and organosulfur compounds are major classes of bioactive compounds. Among them, carotenoids (E160, E161, E164), chlorophylls (E140, E141), flavonoids (anthocyanin (E163)), and betalains (E162) are commonly used as natural colorants in food and cosmetic industries (Table 1) [3,25,28]. Since these compounds have characteristic absorption in the visible spectrum, it is possible to quantify them through UV-visible spectrophotometer within 380-700 nm wavelength range following Beer-Lambert's law.

- Carotenoids, 40 carbon atoms possessing terpenoids, are derived from the condensation of geranylgeranyl-PP molecules [29]. They are lipid-soluble, basically found in cyanobacteria, algae, plants, some fungi and bacteria, and are produced intracellularly by bioproduction of microorganisms [29,30]. Based on their chemical structure, they can be classified as hydrocarbon carotenoids and xanthophylls, and their extraction can easily be performed with nonpolar solvents [29].

- Flavonoids are water-soluble compounds, consisting of 15 carbon atoms (C6-C3-C6) and belong to the class of phenylpropanoids [21,31,32]. Flavonoids furnish intense color, texture, and taste in fruits and flowers, stretching to a wide range of fruit and vegetable parts mostly leaves, flowers, and skin of the fruits $[17,27]$. The color variety and classification differ according to the 
structural groups such as hydroxyl, methyl, glucosyl, and acyl [32]. Anthocyanins (glycosylated and acylated) are groups of flavonoids derived from phenylalanine conferring coloration from pale yellow to blue with respect to $\mathrm{pH}$ changes [32]. Anthocyanins possess several therapeutic properties as they strongly exhibit free radical scavenging capacity [17]. They are abundantly found in berries, blackcurrant, and other purple color giving fruits and vegetables with host taste attributes $[17,28]$.

- Both anthocyanin and betalain (betacyanin) have UV protectable ability for host plant tissues [28]. Betalains have a wider range of $\mathrm{pH}(3-7)$ with yellow to red coloration within that range though less stable to temperature and light exposure as compared to anthocyanin [33]. Slavov and coworkers [34] investigated the color pattern resulting from a mixture of betalain and anthocyanin-rich fruit juices accompanying their functional properties as their coexistence has never been explored.

Table 1. Natural colors applied in the food and cosmetic industries, their E numbers, and common sources $[3,25,28,35,36]$.

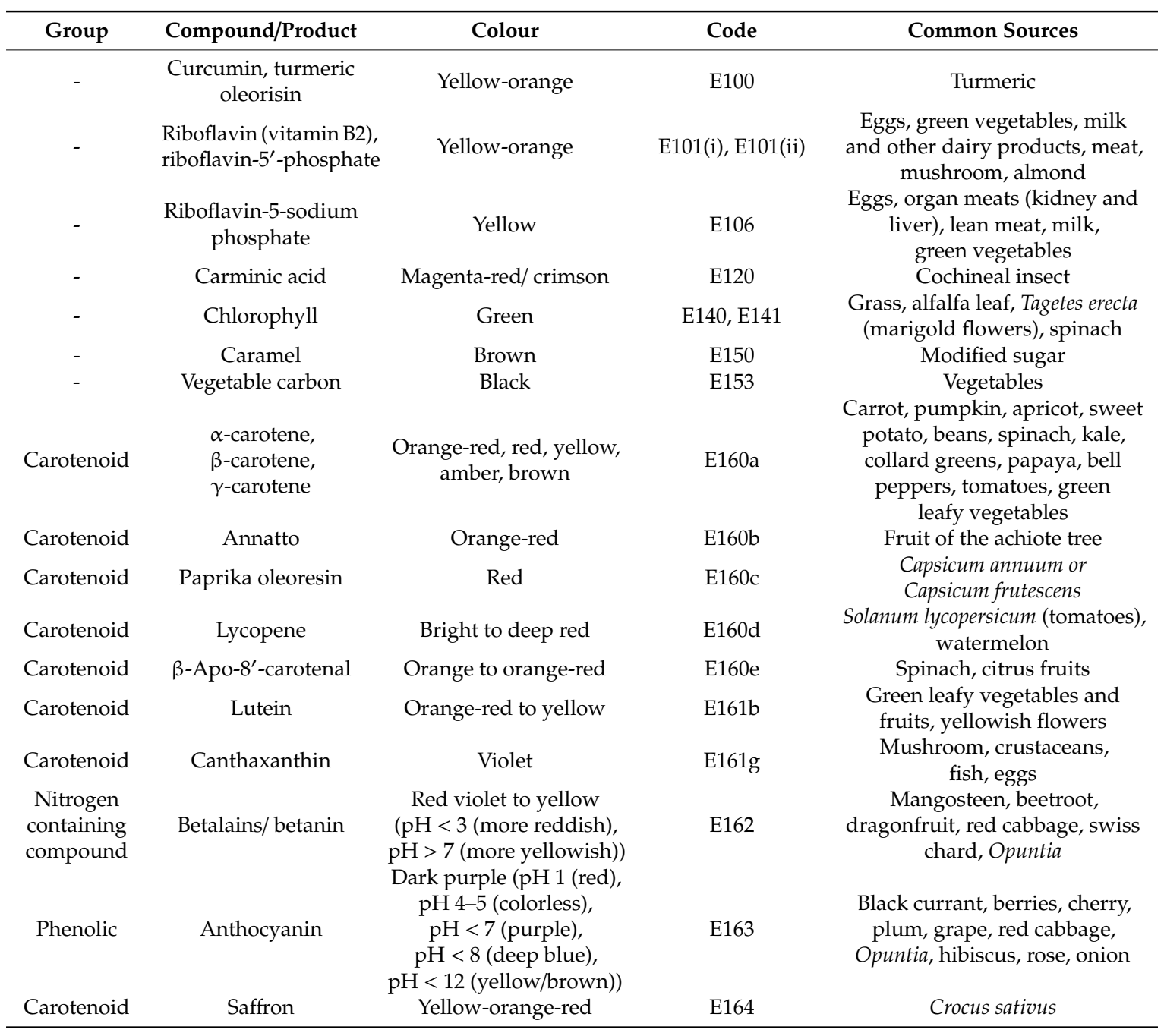

\subsection{Betalains}

Betalains are the main compounds associated with the displayed red color of flowers, fruits, and other plant tissues. Betalains are derivatives of tyrosine which are normally found in plant groups in the order of Caryophyllales including Amaranthaceae (Beta vulgaris), Cactaceae (Opuntia, Pitaya, or Pitahaya), Nyctaginaceae (Bougainvillea), Phytolaccaceae (Phytolacca americana), 
and Portulacaceae (Portulaca grandiflora) [2,3,27,37]. In Caryophyllaceae and Molluginaceae families, anthocyanin is more pronounced than betalain [2,28,32]. Their existence in high-class fungi, for example, agaric Amanita muscaria, Hygrocybe, and Hygrophorus have been reported as well $[2,27,33,38]$. Betalain compounds are accumulated in plant cell vacuoles, predominantly located in edible parts of plant tissues (epidermal and subepidermal), accompanied by other phytochemical compounds $[4-6,37,39]$. Betalains are nitrogen-containing heterocyclic compounds with high water affinity. Their exhibition of antioxidant activity is mainly based on their functional structure, for example, betalamic acid possesses conjugated double bonds that serve as reducing agents via electrons sharing [4]. Additionally, their ability to stabilize even after electron donation is responsible for its antioxidant property [4]. Depending on the type of groups (imino compounds or amino acid/derivatives) attached to the chromosphere of betalains, which is betalamic acid [4-(2-oxoethylidene)-1,2,3,4-tetrahydropyridene-2,6-dicarboxylic acid], two basic color compounds are derived [2,4-6,14,28,33,37,38]. Betaxanthin is obtained by conjugating betalamic acid with amines or amino acids, whereas betacyanin is derived from the condensation of cyclo-L-(3, 4-dihydroxylphenylalanine), known as cyclo-DOPA, or its glucosyl derivatives $[2-6,14,27,28,33,37,38]$ (Figure 1). In the UV visible region, betaxanthin and betacyanin are detectable at the maximum wavelength absorption of 480 and $540 \mathrm{~nm}$, respectively [27]. Betacyanin is responsible for the red color but also more tolerant to heat and stable to processing conditions than the yellow color giving betaxanthin $[3,9,39]$.

Betaxanthin sources are limited, which makes for their low market demand despite their availability in the form of essential dietary amino acids, luckily, Celosia species are available as alternative sources of bright yellow color betaxanthin [40]. Indicaxanthin with prolin group (abundant in Opuntia species) and vulgaxanthin I (Figure 1d) with glutamine substituent, mostly found in Beta vulgaris species, are two prominent yellow color giving betaxanthins $[4,27,28,37]$. Their presence incites the fluorescence property of betaxanthin [4,38]. From the findings of Mikołajczyk-Bator and Pawlak [41], thermal degradation of red-violet pigments was three times lower than yellow color given compounds despite the antioxidant capacity of the latter, which tends to be higher after heat treatments.

Betanin, gomphrenin, amaranthin, and bougainvillein are four major types of betacyanin differed by the substituent groups attached to cyclo-DOPA moiety in ortho position (Figure 1g) $[3,4,33,37,38]$. Betanidin is the basic structural unit of most betacyanin derivatives, followed by, betanin (betanidin 5 -O- $\beta$-glucoside) derives from glucosylation and acylation of aglycon betanidine (I) $[3,27,33,37]$. Betanin is the most stable red color compound, and its antioxidant ability is based on its donation of hydrogen and electron [4]. Presence of glucosyl substituent in C-6 hydroxyl group position and amine group in the ring system encourages radical scavenging activity of betacyanin [33,41], attributes of its anti-oxidative stress-related disorders, anti-cancer, and anti-inflammatory properties in specific plants and vegetables [33]. Phyllocathin (betanidin 5 -O- $\beta$-malonyl-glucoside) and hylocerenin (betanidin 5-O- $\beta$-[3"-hydroxyl-3"-methyl-glutaryl] glucoside) are acylated forms of betacyanin [37]. In addition, isobetanin, betanidin, isobetanidin, prebetanin, neobetanin coexist in a small amount apart from betanin $[4,34]$. Those neo-derivatives are of interest due to their yellow color appearance derived from thermal degradation of Beta vulgaris and Opuntia species betanin [37]. Most degradation processes of betacyanin are isomerization, deglycosylation, dehydrogenation, hydrolysis, and decarboxylation [5,37,41]. 
(a)<smiles>O=CC=C1C=C(C(=O)O)N[C@H](C(=O)O)C1</smiles>

Betalamic acid

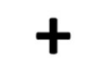<smiles>O=C(O)[C@H]1Cc2cc(O)c(O)cc2N1</smiles>

cyclo-DOPA (b)<smiles>[R][C@@]([CH])(N)C(=O)[O-]</smiles>

Amino acid

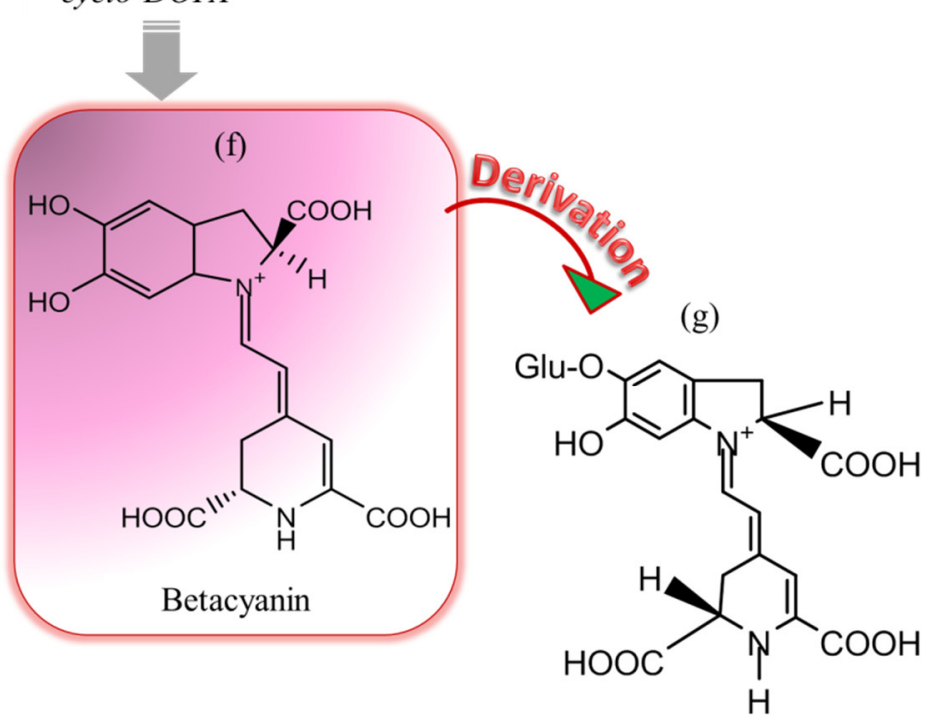<smiles>NC(=O)CC[C@H](N=C/C=C/C1=CC(C(=O)O)N[C@H](C(=O)O)C1)C(=O)O</smiles>

Vulgaxanthin I

Betanin

Figure 1. Derivation of betacyanin and betaxanthin color compounds from betalamic acid: (a) Betalamic acid which is core structure of betalain, (b) Amino acid which conjugates with betalamic acid to derive betaxanthin, (c) Yellow color giving betaxanthin, (d) Vulgaxanthin I which is a derivative of betaxanthin, (e) cyclo-DOPA which condenses with betalamic acid to give betacyanin, (f) Red-violet color giving betacyanin, and (g) Betanin which is a derivative of betacyanin $[2,5,14,27,28,37,42]$.

Color variety of betalains is influenced by yellow color content to some extent [25], and their stabilities are determined by $\mathrm{pH}$, light, heat, water activity, chelating agents, antioxidants, enzymatic reactions $[4,37,43]$. Peroxidases (POX), polyphenol oxidases (PPO), $\beta$-glucosidase, and betalain oxidase are the most responsible enzymes for betalain degradation during processing [14,37]. The disturbance of some endogenous enzymes can be overcome by blanching at $70^{\circ} \mathrm{C}$ for 2 min $[13,27]$. Betalain colorants are available in the form of concentrates [44] and dried powder through air, freeze, or spray drying $[43,45]$, and are normally used in dairy and confectioneries and even in meat products $[27,46]$, although addition in cold products is preferable because of their thermal sensitiveness. Furthermore, Sivakumar and coworkers [47] investigated their application for leather dying through 
the sonic extraction method. Coating of betalain pigments extracted from skin and pulp of Cactus fruit with acidified mucilage from the pulp of the fruit [48] or ionic gelation [49] can extend the shelf life as well as the stability of the pigments. Microencapsulation of beetroot pomace extracts and their applications in bakery products have also been explored recently [50].

\subsection{Phenolic Compounds}

Phenolic compounds $\left(\mathrm{C}_{6} \mathrm{H}_{5} \mathrm{OH}\right)$, also known as polyphenols, are aromatic metabolites made up of a polar functional $(-\mathrm{OH})$ group bonded directly to an aromatic hydrocarbon ring [21]. Their ease of bonding to hydrogen raises their hydrogen bond formation ability for efficient water solubility in aqueous media [4]. Phenolic compounds are derivatives of aromatic amino acid phenylalanine ubiquitous in most plant kingdom with different glycosylated forms ranging from a simple phenolic molecule to high complex polymer molecules $[21,51]$. They are mostly localized in plant tissues $(0.5-5 \mathrm{~g}$ in $100 \mathrm{~g}$ of dry weight) imparting pigments to their host [51]. As aromatic secondary metabolites, phenolics are anti-inflammatory, antimicrobial, and antithrombotic. They are willing to donate their electrons from the outermost shell to fulfil the leakage of free radicals and can extend the shelf-life of food products $[16,17,21,52]$. Consequently, phenoxyl radicals (PhO) are developed after transferring the hydrogen atom to free radical, which in turn can conjugate with adjacent hydroxyl or amine groups to enhance their stabilities, making them resistant to further oxidation process [4].

Based on carbon atom numbers, phenolics, flavonoids, and tannins upon derivatization possess specific structures [21]. Among them, phenolic acids and flavonoids are the most active plant-based phenolic compounds (30\% and 60\% of total dietary polyphenols content) (Figure 2), they can easily be extracted with water, supercritical or subcritical water, and alcoholic solvents [17,53,54]. Benzoic acid derivatives $\left(\mathrm{C}_{6}-\mathrm{C}_{1}\right)$ and cinnamic acid derivatives $\left(\mathrm{C}_{6}-\mathrm{C}_{3}\right)$ are the two main classes of phenolic acids [21], whereas flavonols, flavones, flavanones, flavanols, isoflavones, flavanonols, and anthocyanidins are unique flavonoid compounds with variation in heterocyclic ring structures $[17,21,31]$.

(a)<smiles>O=C(O)c1ccccc1O</smiles>

Phenolic acid (b)

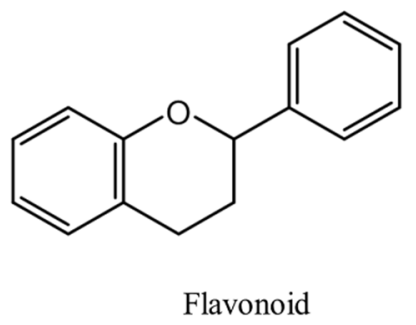

Figure 2. Basic structures of phenolic compounds: (a) Backbone structure of phenolic acid, and (b) Structure of flavonoid moiety $[21,31]$.

\section{Generalities of Solid-Liquid Extraction}

Classical extraction of target compounds from different types of matrix can be achieved through several cold or hot extraction methods: distillation; solvent extraction such as percolation, maceration, infusion, enfleurage; and cold compression [55]. Solvent selection should be suited with specific properties of compounds of interest. Apart from water, polar solvents such as alcoholic solvents are extensively used to upgrade extraction efficiency, although there are some oppositions of their application in the matter of total solid content increase [56]. Between $20 \%-50 \% v / v$ methanol or ethanol are the fundamentally used solvents for complete extraction of betalains. Being a non-toxic green solvent, extractions with ethanol solvent do not need any further purification step, while methanol is preferable for denaturation of enzymes and for overcoming the interference of water-soluble protein $[14,27,33]$. Biosynthesis reaction of compounds present in the matrix can be handled by acidifying the extraction medium; for example, enzymatic decolorization of betalain can be retarded by ascorbic acid, which interferes with oxidative activity of polyphenol oxidases or B-gluconolactone 
and inhibits B-glucosidase [33]. Moreover, ascorbic acid has some preservative effects on Amaranthus betacyanin, improved the stability of red color betalain, and upgraded yield of betanin to the highest as well [57]. However, as exogenous antioxidants, care should be taken in the application of ascorbic acids for antioxidant activity determination [14]. Chelating agents such as citric acid and EDTA (ethylene-diamine-tetra-acetic acid) are also prominent for acidification extraction of bioactive compounds in order to boost their yield [4]. In some cases, inorganic acid like hydrochloric acid is favorable to prevent the activity of endogenous enzymes [8,27].

\section{Emerging Technology}

Handling of perishable vegetables is a big challenge for food processing industries and has led to the innovation of processing techniques to assure food quality and at the same time minimize food loss. Minimal processing is the preparation of food with minimal treatment and the smallest changes in food quality through modern processing technology. Attempts have been made to bring practical usage from emerging technologies to minimal food processing in the areas of tempering, vacuum drying, freeze-drying, dehydration, cooking, baking, roasting, pasteurization, sterilization, extraction, blanching, and direct microwave blanching [58]. Based on the characteristics of targeted products, thermal treatment methods (ultra-high temperature processing, aseptic or semi-aseptic heat treatment, sous-vid, infrared heating, high frequency or radiofrequency heating, ohmic heating, microwave heating, inductive electrical heating, etc.) and non-thermal treatment methods (low direct current electric fields, ionizing radiation, gamma irradiation, pulsed electric fields (PEF), UV light, pulsed light, laser light heating, ultrasonic wave heating, high-pressure processing, etc.) have been developed [59]. Currently used emerging technologies for the extraction of secondary plant metabolites (betalains and phenolic compounds) are microwave-assisted extraction (MAE), ultrasonic-assisted extraction (UAE), high pressure and temperature extraction (HPTE), supercritical fluids extraction (SFE), pressurized liquids extraction (PLE), pulse electric field extraction (PEF), gamma-irradiation-assisted extraction, and extraction by low direct current electrification $[7,8,16,18-20,24,34,42,46,47,52,54,57,60-90]$.

\subsection{Microwave Irradiation}

In green chemistry, MAE is a well known novel technology with comparative advantages of reaction time reduction and lower or no solvent requirement over conventional extraction techniques [91]. Electromagnetic waves with frequencies between $300 \mathrm{MHz}$ and $300 \mathrm{GHz}$ are noted as microwave and previously applied for navigation and telecommunication operations [53,92]. Based on their application purposes, two frequency ranges are classified as $2450 \mathrm{MHz}$ for home usage with adjustable power output $<1000 \mathrm{~W}$ and $915 \mathrm{MHz}$ for the industrial one [23,53,55,91]. Being a segment of the electromagnetic spectrum, like visible light, the phenomenon of bending, reflection, refraction, and absorption of microwave radiation by the medium through which it passes are unavoidable [92]. Likewise, the degree of absorptivity or transmissivity of transmitted waves relies on the electromagnetic properties of the treated object, for instance, dielectric property, polarity, permittivity, and the shape of the object. Another important factor is in situ water content of the matrix as the level of swelling and rupture of the matrix can be varied with it [93]. The contradiction of electromagnetic wave is based on its electric and magnetic wave propagation oscillating in a perpendicular direction to each other with wavelength $(1 \mathrm{~m} \sim 1 \mathrm{~mm})[23,53,55,91]$. Herein, the electric part if only absorbed by natural biological materials [94] consequently leads to heating process occurring in the medium with absorption property of microwave $[55,91]$. Microwave radiation is non-ionized with photon energy ranging from $3.78 \times 10^{-6} \mathrm{eV}$ to $1.01 \times 10^{-5} \mathrm{eV}$, and interaction process occurs by heat conduction mode [55]. Moreover, the transformation phenomenon of kinetic to thermal energy is mainly concerned with the polarization potential of the polar molecules and their surroundings [23,92]. The protocol is that once polar molecules present in a substance are hit by the electromagnetic beams, they become energetic and swing with the alternative movement of electric field, and consequently the alternative action of alignment and realignment of polar molecules creates friction between them, which in turn lead to the 
heating up of the surroundings [53,92] (Figure 3). Meanwhile, ionic components which are present in the substance migrate according to the electric field [91] (Figure 3). This intermolecular friction and ionic movements occur several million times $\left(4.9 \times 10^{9}\right.$ times at a frequency of $\left.2450 \mathrm{MHz}\right)$ per second and raise the internal pressure of cell [91]. Consequently, higher internal pressure encountered due to rapid vaporization of in situ water could rupture the cell wall and enclosed substances inside the cell wall could be forced out of the cell at a high rate [23].
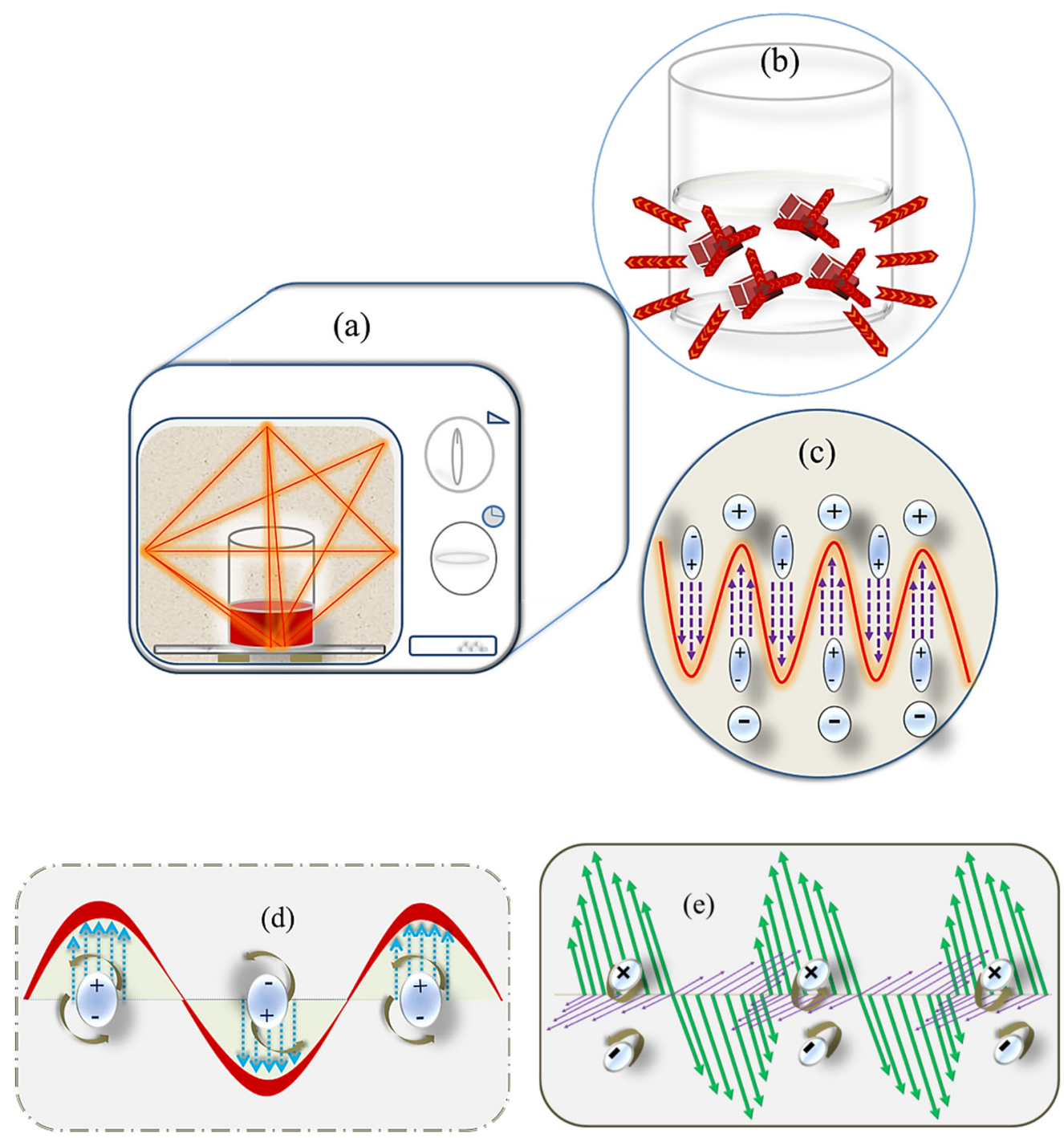

Figure 3. Treatment of microwave heat radiation for secondary plant metabolites extraction: (a) Domestic microwave oven heating system, (b) Heat diffusion from inside of the matrix to solvent medium and the surroundings, (c) Alignment of dipolar molecules and ions with electromagnetic wave, (d) Friction and rotation of dipolar molecules which heat up the matrix, and (e) Movements of ions with the electromagnetic wave.

\subsection{Mathematical Terms}

Electric loss tangent $(\tan \delta)$ of materials, which is also known as dissipation factor, quantifies the transformation of electric and magnetic energy to thermal energy in the materials; it can be explained in terms of dielectric loss $\left(\varepsilon^{\prime \prime}\right)$ and dielectric loss constant $\left(\varepsilon^{\prime}\right)$ as given below in (Equation $\left.(1)\right)[23,91,92,94]$ :

$$
D_{f}=\tan \delta=\frac{\varepsilon^{\prime \prime}}{\varepsilon^{\prime}}
$$


Absorption, transmission, and reflection abilities of different materials, known as electric permittivity, can be tracked in several ways. The absolute permittivity elucidates only how the material interacts with applied electromagnetic waves for nonionizing radiation and nonmagnetic materials [94]. Alternatively, it can be said that nonmagnetic materials rely on dielectric permittivity $\left(\varepsilon^{*}\right)$ to interact with electromagnetic waves and can be expressed by dielectric constant $\left(\varepsilon^{\prime}\right)$ and dielectric loss $\left(\varepsilon^{\prime \prime}\right)$ shown in (Equation (2)); [94]:

$$
\varepsilon^{*}=\varepsilon_{r}^{\prime}-j \varepsilon_{r}^{\prime \prime}
$$

Real and imaginary parts of permittivity represent dipolar oscillation and damping [92], and are valued depending on the motion of dipoles, nature of materials, high or low frequency, elevated or reduced temperature, and also the concentration of aqueous ionic solution [94]. Commonly used solvents with their loss tangent values are listed in Table 2. Relative permittivity $(\varepsilon)$ can be estimated from electric displacement field of material $\left(D, C \cdot \mathrm{m}^{-2}\right)$ which is divided by vacuum $\left(D_{\text {vacuum }}\right.$, $C \cdot \mathrm{m}^{-2}$ ) [92]. In dielectric material, conversion of electrical energy into thermal energy is defined by its loss factor. Consequently, dipole rotation and electrical conduction are assumed as loss factors in microwave heating, (Equation (3)):

$$
\varepsilon_{r}^{\prime \prime}=\varepsilon_{d}^{\prime \prime}+\varepsilon_{\sigma}^{\prime \prime}
$$

where $\varepsilon_{\mathrm{d}}$ " is relative dipole loss and $\varepsilon_{\sigma}$ " is relative ionic loss.

Table 2. Reported mathematical parametric values associated with commonly used solvents for phytochemical recovery through MAE (Microwave-Assisted Extraction).

\begin{tabular}{ccccc}
\hline Solvent & Loss Tangent & Dielectric Constant $\left(\varepsilon^{\prime}\right)$ & Dielectric Loss $\left(\varepsilon^{\prime \prime}\right)$ & Reference \\
\hline water & 0.123 & 80.4 & 9.8892 & {$[23,53,58]$} \\
ethanol & 0.941 & 25.7 & 24.1837 & {$[23,53]$} \\
methanol & 0.659 & 32.7 & 21.5493 & {$[23,53]$} \\
acetone & 0.054 & 20.6 & 1.1124 & {$[53]$} \\
\hline
\end{tabular}

If the components are homogeneous, their shape is more responsible for the effective permittivity of the mixtures, especially when the particle size is smaller than the wavelength [94]. Literally, ordinary foods possess the penetration depth of electromagnetic waves $(10-15 \mathrm{~mm})$ [94]. The penetration level of microwave through the substance can be traced by the degree of reflection, transmission, and absorption of the wave by the host substance; for example, pure water has a low degree of reflection and transmission but a high degree of absorption of the wave [92]. Dissipated microwave power $\left(P_{D}, \mathrm{~W}\right)$ in a material can be estimated from electric field strength $\left(E, \mathrm{~V} \cdot \mathrm{m}^{-1}\right)$, and frequency $(f, \mathrm{~Hz})$ as reported by [92,94] (Equation (4)):

$$
P_{D}=k \cdot E^{2} \cdot f \cdot \varepsilon^{\prime \prime}
$$

where $k$ is a constant value of $55.61 \times 10^{-14} \mathrm{C} \cdot \mathrm{m}^{2} \cdot \mathrm{V}^{-1}$. Due to direct proportionality of dissipated microwave power $\left(\mathrm{P}_{\mathrm{D}}\right)$ to the absorptivity of the material, the attenuation of microwave differs according to the depth of penetration (z) and can be estimated as expressed in Equation (5):

$$
z=\frac{\lambda}{2 \pi} \cdot \sqrt{\frac{2}{\varepsilon^{\prime}\left(\sqrt{1+\tan ^{2} \delta}-1\right)}}
$$

Frequency of applied radiation $(\mathrm{f}, \mathrm{Hz})$ and speed of the wave $\left(\mathrm{c}, \mathrm{m} \cdot \mathrm{s}^{-1}\right)$ can be used to evaluate wavelength $(\lambda, \mathrm{m})$ [92].

\subsection{Microwave-Assisted Extraction (MAE) of Betalains and Phenolic Compounds}

Microwave irradiation is proposed as an effective alternative way of recovering bioactive compounds from agro-industrial wastes with superior benefits such as high reproducibility within 
short treatment period, minimal solvent and energy consumption, and simple manipulation as opposed to classical solid-liquid-based extraction methods (soxhlet, rotary, maceration, and heat refluxing), supercritical water extraction, and even ultrasonic extraction [16,18,20,52,54,60-64]. In advance, MAE has brought 1.7 times greater yield percent of phenolic [65], whilst operation time was two times shorter than UAE [54]. Alongside, 5 min of microwave irradiation could bring an equivalent amount of phenolic and flavonoid compounds with an hour of ultrasonic treatment time [61]. However, UAE was pointed out as the better choice in the investigations of [22,63], in this case, the discrepancy in applied frequency and power wattage should be taken into account. Somehow, it is undeniable that both MAE and UAE are better in internal or external mass transfer compared to classical methods. In UAE, the formation of tiny gas bubbles in the solvent medium by mechanical wave encourages several micro-injections into the cell wall, which improves the solvent transport. Herein, sonication of water can propagate highly reactive hydroxyl radicals which may have some effect on the extraction of targeted products $[52,66]$.

Heating mode, duty cycle, power or heat energy, and temperature in an advanced microwave set up are basic operational parametric modes in MAE of betalains and phenolic compounds. Response surface methodology (RSM) is a suitable tool to approach the efficiency of MAE through the interaction of process variables despite the fact that the predicted values estimated by the model are only within the experimental limit $[9,18,62,63,67-73]$. Central composite design was mostly chosen for the investigation of each or parallel effects of process variables on the corresponding response. Based on the response level whether high or low, the weight of the factor on the response could be judged. Here again, the levels of the factors optimized by RSM support to be in between, i.e., neither at most nor lowest level or else the performed limits are regarded as insufficient for the design to fully predict the optimum condition of the variables within those limits [26]. For example, it can be said that the model well predicted the optimum condition of the extraction process if the highest amount of total phenolic compounds (39 $\mathrm{mg} \mathrm{GAE} / \mathrm{gDW}$ ) was achieved at ethanol concentration (31.33\%), solvent to material ratio $(32.21 \mathrm{~mL} / \mathrm{g})$, temperature $\left(52.24{ }^{\circ} \mathrm{C}\right)$ among the variables which were ethanol concentration (20-40\%), solvent to material ratio $(20-40 \mathrm{~mL} / \mathrm{g})$, temperature $\left(40-60{ }^{\circ} \mathrm{C}\right)$ [73]. Tables 3 and 4 represent some reported optimum conditions, within experimental variable ranges, for the extraction of betalains and phenolic compounds from fruit and vegetable as well as their wastes. In advance, some example of power output and time setting to accomplish MAE of secondary plant metabolites are demonstrated in Figures 4 and 5.

Table 3. Recovery of betalain color compounds through microwave irradiation.

\begin{tabular}{|c|c|c|c|c|c|c|}
\hline \multirow{2}{*}{ Raw Material } & \multirow{2}{*}{ Solvent } & \multirow{2}{*}{ Product } & \multicolumn{3}{|c|}{ Process Optimum Conditions } & \multirow{2}{*}{ Reference } \\
\hline & & & Results & Time & Power & \\
\hline \multirow[t]{2}{*}{ Red beetroot peel } & $\begin{array}{l}\text { acidified } \\
\text { water }\end{array}$ & betanin & $\begin{array}{c}229.26 \text { mg/L } \\
\text { (predicted by RSM) }\end{array}$ & $0.95 \mathrm{~min}$ & $224.61 \mathrm{~W}$ & [8] \\
\hline & ethanol & & $\begin{array}{c}472.11 \mathrm{mg} / \mathrm{L} \\
\text { (predicted by RSM) }\end{array}$ & $1.25 \mathrm{~min}$ & $384.25 \mathrm{~W}$ & \\
\hline Red beetroot & $\begin{array}{l}\text { pure water } \\
\text { acidified } \\
\text { water }\end{array}$ & $\begin{array}{l}\text { betaxanthin } \\
\text { betacyanin }\end{array}$ & $\begin{array}{l}1.25 \mathrm{mg} / \mathrm{g} \text { of freeze dried } \\
\text { red beet } \\
1.88 \mathrm{mg} / \mathrm{g} \text { of freeze dried } \\
\text { red beet }\end{array}$ & $2.2 \mathrm{~min} / 1.7 \mathrm{~min}$ & $\begin{array}{c}400 \mathrm{~W} \\
100 \% \text { nominal }\end{array}$ & [24] \\
\hline Red beetroot & pure water & $\begin{array}{l}\text { betacyanin } \\
\text { betaxanthin }\end{array}$ & $\begin{array}{l}52.2 \mathrm{mg} / \mathrm{g} \text { of fresh matter } \\
42.8 \mathrm{mg} / \mathrm{g} \text { of fresh matter }\end{array}$ & $3 \min \times 4$ times & $450 \mathrm{~W}$ & {$[34]$} \\
\hline Opuntia fruit peel & $\begin{array}{c}34.6 \% \\
\text { methanol }\end{array}$ & betalain & $201.6 \mathrm{mg} / \mathrm{g}$ of extract & $2.5 \mathrm{~min}$ & $400 \mathrm{~W}$ & [63] \\
\hline Dragon fruit peel & pure water & betalain & $\begin{array}{c}9 \mathrm{mg} / \mathrm{L} \\
\text { (predicted by RSM) }\end{array}$ & $8 \mathrm{~min}$ & $100 \mathrm{~W}$ & {$[72]$} \\
\hline $\begin{array}{l}\text { White-fleshed red } \\
\text { pitaya peel }\end{array}$ & pure water & betacyanin & $1.66 \mathrm{mg} / \mathrm{g}$ of dry extract & $5 \mathrm{~min}$ & $600 \mathrm{~W}$ & {$[74]$} \\
\hline
\end{tabular}


Table 4. Total phenolic compound (TPC) recovery by microwave radiation treatment.

\begin{tabular}{|c|c|c|c|c|c|c|}
\hline \multirow{2}{*}{ Raw Materials } & \multirow{2}{*}{ Extraction } & \multirow{2}{*}{ Analytical Method } & \multicolumn{3}{|c|}{ Process Optimum Conditions } & \multirow{2}{*}{ Reference } \\
\hline & & & Results & Time & Power & \\
\hline Coriandrum sativum (spice) & & & $0.82 \mathrm{mg}$ GAE$/ \mathrm{g}$ of DW & & & \\
\hline Cinnamomum zeylanicum (spice) & & & $16.8 \mathrm{mg}$ GAE/g of DW & & & [16] \\
\hline Cuminum cyminum (spice) & $50 \%$ ethanol & FC & $11.6 \mathrm{mg}$ GAE/g of DW & $18 \mathrm{~min}$ & $200 \mathrm{~W}, 50 \%$ nominal & [16] \\
\hline Crocus sativus (spice) & & & $29.4 \mathrm{mg}$ GAE/g of DW & & & \\
\hline $\begin{array}{l}\text { Lessonia trabeculate } \\
\text { (Brown algae) }\end{array}$ & & & $0.74 \mathrm{mg}$ GAE/g of DW & & & \\
\hline $\begin{array}{l}\text { Lessonia nigrecens } \\
\text { (Brown algae) }\end{array}$ & $70 \%$ methanol & FC & $1.07 \mathrm{mg}$ GAE/g of DW & $15 \mathrm{~min}$ & intermittent & {$[20]$} \\
\hline $\begin{array}{l}\text { Ascophyllum nodosum } \\
\text { (Brown algae) }\end{array}$ & & & $1.4 \mathrm{mg} \mathrm{GAE} / \mathrm{g}$ of DW & & & \\
\hline $\begin{array}{l}\text { Laminaria japonica } \\
\text { (Brown algae) }\end{array}$ & & & $0.73 \mathrm{mg}$ GAE/g of DW & & & \\
\hline Rosemary & $\begin{array}{l}96 \% \text { ethanol } \\
\text { pure water }\end{array}$ & FC & $\begin{array}{l}0.9 \mathrm{mg} \mathrm{GAE} / \mathrm{g} \text { of fresh leaf } \\
0.1 \mathrm{mg} \mathrm{GAE} / \mathrm{g} \text { of fresh leaf }\end{array}$ & $7 \mathrm{~min}$ & $250 \mathrm{~W}$ (intermittent) & [52] \\
\hline $\begin{array}{l}\text { Grape seed } \\
\text { Grape skin }\end{array}$ & methanol & $\mathrm{FC}$ & $\begin{array}{l}67.88 \mathrm{mg} \mathrm{GAE} / \mathrm{g} \text { of DW } \\
7.33 \mathrm{mg} \text { GAE} / \mathrm{g} \text { of DW }\end{array}$ & $60 \mathrm{~min}$ & $60 \mathrm{~W}$ & {$[60]$} \\
\hline Eucalyptus leaf & $50 \%$ ethanol & FC & $76.6 \mathrm{mg} \mathrm{GAE} / \mathrm{g}$ of fresh leaf & $5 \mathrm{~min}$ & $600 \mathrm{~W}$ (intermittent) & [61] \\
\hline Olive leaf & $50 \%$ ethanol & FC & $88.3 \mathrm{mg}$ TAE$/ \mathrm{g}$ of DW & $15 \mathrm{~min}$ & intermittent & {$[64]$} \\
\hline Peanut skin & $30 \%$ ethanol & FC & $\begin{array}{l}143.6 \mathrm{mg} \text { GAE/g of skins } \\
\text { (predicted by RSM) }\end{array}$ & $0.5 \mathrm{~min}$ & $950 \mathrm{~W}, 90 \%$ nominal & {$[67]$} \\
\hline Broccoli & $72.06 \%$ methanol & FC & $21.39 \mathrm{mg} \mathrm{GAE} / \mathrm{g}$ of DW & $16.94 \mathrm{~min}$ & $159.33 \mathrm{~W}$ & [68] \\
\hline Wine lee & $\begin{array}{l}\text { 75\% ethanol } \\
\text { (acidified) }\end{array}$ & FC & $36.4 \mathrm{mg} \mathrm{GAE} / \mathrm{g}$ of lee extract powder & $17 \mathrm{~min}$ & $200 \mathrm{~W}$ & [69] \\
\hline $\begin{array}{c}\text { (Ipomoea Batatas) } \\
\text { Sweet potato leaf }\end{array}$ & $53 \%$ ethanol & $\mathrm{FC}$ & 61.26 mg GAE/g DW & $2.05 \mathrm{~min}$ & $302 \mathrm{~W}$ & [71] \\
\hline Melastoma sanguineum Fruit & $31.33 \%$ ethanol & FC & $39.02 \mathrm{mg} \mathrm{GAE} / \mathrm{g}$ of DW & $45 \mathrm{~min}$ & $500 \mathrm{~W}$ & [73] \\
\hline Lycium spp. leaf & pure methanol & FC & $6.65 \mathrm{mg}$ GAE/g of DW & $30 \mathrm{~min}$ & $40 \mathrm{~W}$ & [75] \\
\hline Buckwheat & $50 \%$ ethanol & FC & $18.5 \mathrm{mg} \mathrm{GAE} / \mathrm{g}$ of buckwheat & $15 \mathrm{~min}$ & - & [76] \\
\hline Pitaya peel & pure water & FC & $5.8 \mathrm{mg} \mathrm{GAE} / \mathrm{g}$ of extract & $20 \mathrm{~min}$ & $400 \mathrm{~W}$ & [77] \\
\hline Sour cherry pomace & $50 \%$ ethanol & FC & $14.14 \mathrm{mg}$ GAE/g of DW & $12 \mathrm{~min}$ & $700 \mathrm{~W}$ & [78] \\
\hline
\end{tabular}

$\mathrm{GAE}=$ gallic acid equivalent, $\mathrm{FC}=$ folin-ciocalteu analytical method, $\mathrm{TAE}=$ tannic acid equivalent, $\mathrm{DW}=$ dry weight. 


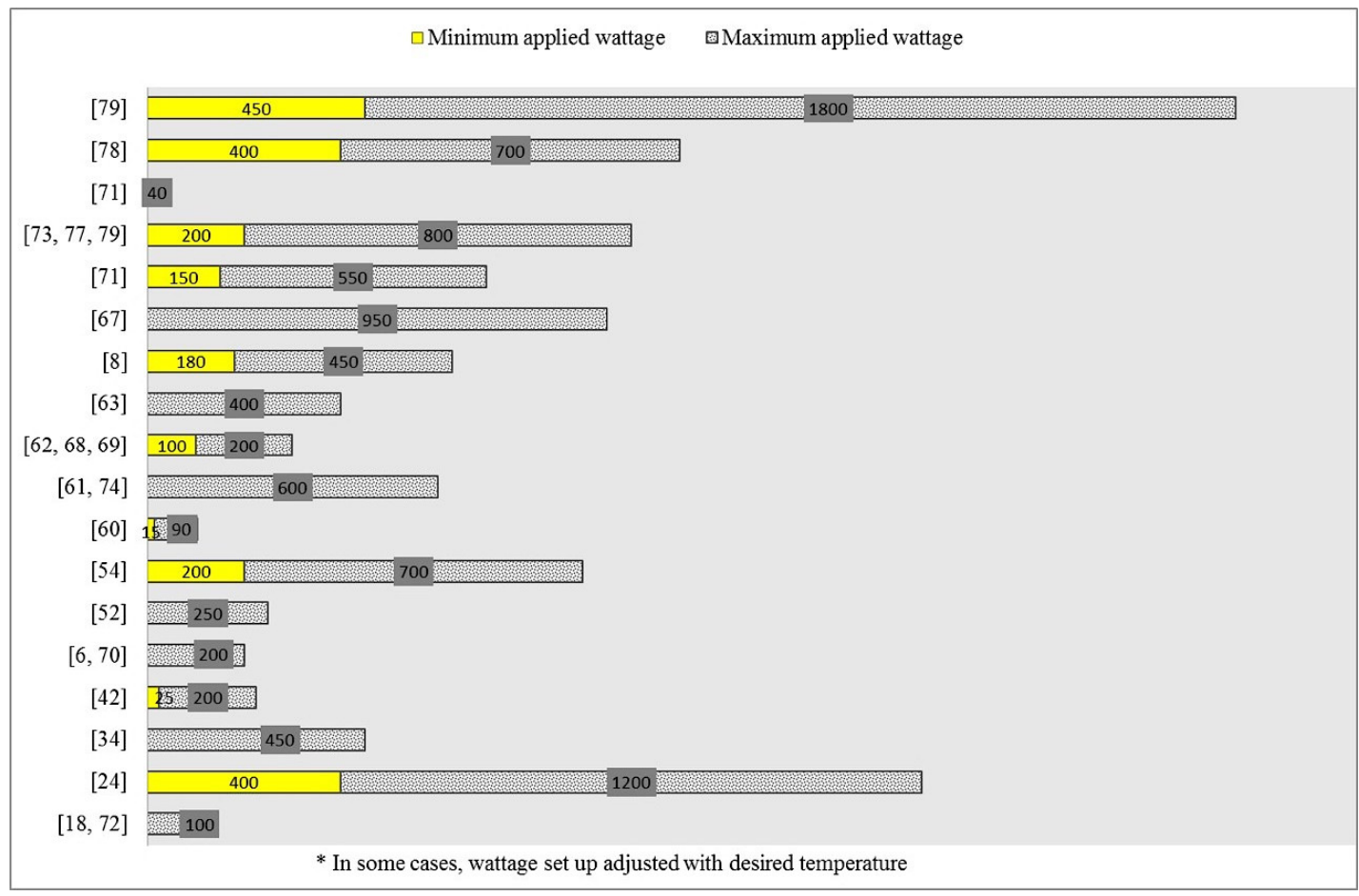

Figure 4. Ranges of power output for extraction of secondary plant metabolites (betalains and phenolic compounds).

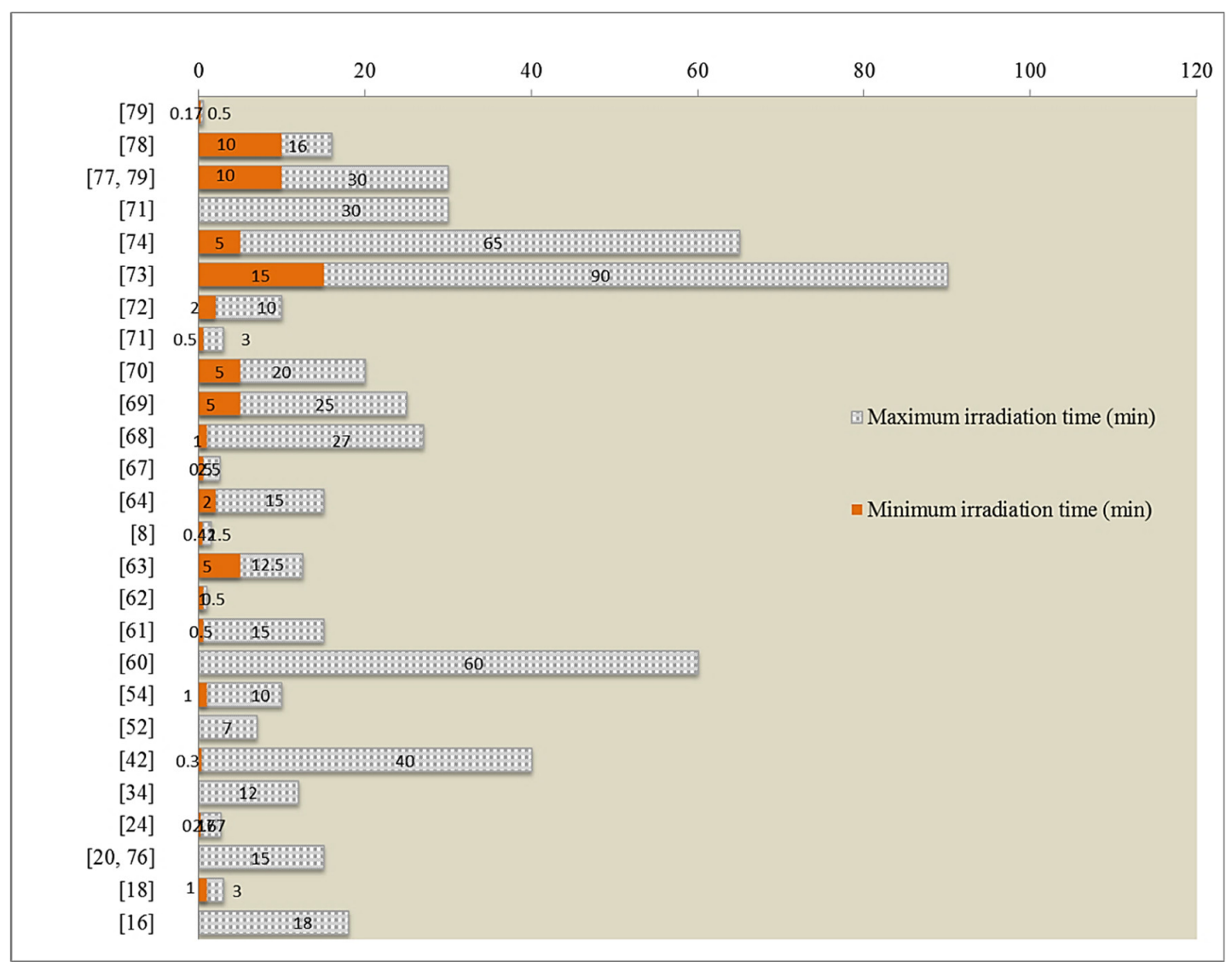

Figure 5. Ranges of microwave irradiation time ( $\mathrm{min}$ ) for extraction of phytochemicals (betalains and phenolic compounds). 
In MAE, both the solvent and the sample undergo transformation by electromagnetic energy of high value based on ionic conduction and dipole rotation (either permanent or induced by the electric field). Ionic conduction, which is due to the electrophoretic migration of dissolved ions, increases solvent penetration into the matrix and facilitates the solvation of targeted compounds [91]. Influence of solvent type on microwave extraction of desired phenolic compound quantity has been investigated with pure water, pure and aqueous forms of acetone, ethanol and methanol, and of them, $50 \%(v / v)$ ethanol was observed to be most effective $[61,64,78,80]$. Presence of a suitable amount of water in the solvent somehow can improve the swelling of the plant matrix, increasing the contact surface area of the matrix with the solvent [62]. However, it is controversial whether inert solvent to microwave radiation is better than the absorbed one or not as acetone performed better in phenolic compounds extraction possibly due to transparent property to microwave radiation subsequently allowing plant cells receive direct contact of the radiation [19]. Moreover, it should be noted that microwave can rapidly lose its energy before it reaches the innermost part of the medium if the medium it passed through is in high absorptivity of radiation [92].

Applied power output for microwave irradiation influences phenolic compounds [73], and it is obvious if irradiation time is short [59], which possibly leads to accelerated diffusion of the solvent into the matrix and in turn leaching out of the materials [23]. Prolonged heating via elevated temperature treatments can jeopardize pigment retentions; in this case, the acidification method can be considered for decompartmentalization of color compounds after microwave treatment [24]. Synergistic effects of processing time and temperature or microwave power, solvent concentration, and matrix-to-solvent ratio on mass transfer rate differ for specific secondary plant compounds, thus process condition adjustment should be focused on targeted compounds in order to distribute radiations uniformly $[17,24,73]$. Reported SEM (scanning electron microscopy) results showed that cell wall thinning and holes formation were prominent in microwave treatment rather than traditional heating modes $[65,80,82,95,96]$. This is because microwave penetrates the matrix and denaturalizes the cell wall in which bioactive compounds are trapped in a short time, subsequently letting them diffuse quickly into the solvent medium. However, the superheating effect can be encountered as a consequence, which is more pronounced with pure water solvent due to its quite low dissipation factor but high dielectric constant, facilitating the absorption of the microwave [92]. Since microwave heating is based on the alignment of the polar molecules back and forth, the transformation of kinetic energy to thermal energy is more intensive when their movement cannot catch up the frequency of applied microwave, which is the so-called dumping process [62]. That is why intermittent modes of microwave irradiation and cooling in between extraction steps were found to be effective [21,24,52,61,64,81].

\section{Other Applications}

Apart from betalain and phenolic compounds, MAE has been widely used in the extraction of pectin with some improvements in quantity and quality, degree of esterification, and gel strength [97]. Moreover, essential oil extractions from different sources via advanced microwave-assisted techniques have been realized $[93,98,99]$. The combination of novel extraction methods which are microwave, ultrasonic wave, enzymatic, and also alkali assisted extraction have been complimented as well $[90,95,100,101]$ (Table 5). Other improved MAE methods are in situ extraction of essential oils with microwave oven [102], MAE of multi-elements from food materials via perchloric acid and hydrogen peroxide [103], MAE and GC-FID quantification of total branched-chain fatty acids in lamb subcutaneous adipose tissue [104]. Additionally, some other modified techniques of microwave irradiation such as vacuum microwave-assisted extraction, nitrogen-protected microwave-assisted extraction, dynamic microwave-assisted extraction, pressurized solvent free microwave-assisted extraction, radiation-assisted hydro-distillation, vacuum microwave hydro-distillation, microwave-assisted steam distillation, vacuum microwave-assisted hydro-gravity, microwave dry-diffusion and gravity have been mentioned in the reviews of $[23,91]$. Apart from extraction, microwave application has been 
extended to processing of beetroots which has more effectiveness in oxidative stability of mayonnaise than roasted or boiled ones, thereby preserving betalains and phenolic compounds [105].

Table 5. Some other applications of advanced MAE and their findings.

\begin{tabular}{|c|c|c|c|}
\hline Sources & Methods & Advantages & References \\
\hline Sorghum husks & $\begin{array}{l}\text { Ultrasonic-microwave assisted } \\
\text { extraction of colorant (UMAE) }\end{array}$ & $\begin{array}{l}\text { Higher in thermal stabilities and yield } \\
\text { percent ( } 3.6 \text { times) with high contents of } \\
\text { apigeninidin and luteolinidin than } \\
\text { conventional shaking }\end{array}$ & [90] \\
\hline Aromatic herbs & $\begin{array}{l}\text { Enhanced solvent free } \\
\text { microwave-assisted extraction } \\
\text { (ESFMAE) }\end{array}$ & $\begin{array}{c}\text { ESFMAE increased in oxygenated } \\
\text { compound content which was more } \\
\text { odoriferous than monoterpene } \\
\text { hydrocarbons }\end{array}$ & [93] \\
\hline Cherry seeds & $\begin{array}{l}\text { Ultrasonic-microwave-assisted } \\
\text { aqueous enzymatic extraction } \\
\text { (UMAAEE) }\end{array}$ & $\begin{array}{l}\text { Compared to Soxhlet extraction, oil by } \\
\text { UMAAEE possessed superior } \\
\text { physicochemical properties and higher } \\
\text { content of bioactive constituents }\end{array}$ & [95] \\
\hline $\begin{array}{c}\text { Tunisian cumin } \\
\text { (Cuminum cyminum L.) } \\
\text { seeds }\end{array}$ & $\begin{array}{l}\text { Microwave hydrodiffusion and } \\
\text { gravity extraction (MHGE) }\end{array}$ & $\begin{array}{c}\text { MHGE successfully improved the EO } \\
\text { yield with high amount of oxygenated } \\
\text { compounds in shorter extraction time, } \\
\text { less electrical consumption, lower } \\
\text { carbon dioxide emissions, and smaller } \\
\text { volume of waste water }\end{array}$ & [96] \\
\hline Rosemary plants & $\begin{array}{c}\text { Microwave hydro-distillation } \\
\text { (MHD) }\end{array}$ & $\begin{array}{l}\text { MHD was superior in terms of saving } \\
\text { energy and extraction time compared to } \\
\text { hydro-distillation }\end{array}$ & [98] \\
\hline $\begin{array}{l}\text { Foeniculum vulgare } \\
\text { Mill. seeds }\end{array}$ & $\begin{array}{c}\text { Enhanced solvent free } \\
\text { microwave-assisted extraction } \\
\text { using double walled reactor } \\
\text { (ESFMAE) }\end{array}$ & $\begin{array}{l}\text { ESFMAE method was faster, cleaner, } \\
\text { less cost and energy usage, and better } \\
\text { essential oil composition than } \\
\text { hydro-distillation method }\end{array}$ & [99] \\
\hline Arabica coffee beans & $\begin{array}{l}\text { Ultrasonic-microwave assisted } \\
\text { extraction of green coffee oil } \\
\text { (UMAE) }\end{array}$ & $\begin{array}{l}\text { Extraction yields of two diterpenes } \\
\text { (cafestol and kahweol) by UMAE were } \\
\text { significantly higher than that of solvent } \\
\text { method }\end{array}$ & [100] \\
\hline Corn brans & $\begin{array}{l}\text { Ultrasonic-microwave assisted } \\
\text { alkali extraction of } \\
\text { arabinoxylan (UMAAE) }\end{array}$ & $\begin{array}{l}\text { By UMAAE, water-unextractable } \\
\text { arabinoxylan (WUAX) showed good } \\
\text { DPPH radical scavenging activity and } \\
\text { strong } \mathrm{Fe}^{2}+\text { chelating activity }\end{array}$ & [101] \\
\hline $\begin{array}{l}\text { Schisandra chinensis } \\
\text { Baill fruits }\end{array}$ & $\begin{array}{c}\text { Ionic liquid-based } \\
\text { microwave-assisted extraction } \\
\text { (ILMAE) }\end{array}$ & $\begin{array}{l}\text { ILMAE method shortened the energy } \\
\text { consumption time, improved the } \\
\text { extraction efficiency of lignans as to } \\
\text { reflux extraction }\end{array}$ & [106] \\
\hline $\begin{array}{c}\text { Flowers of } \\
\text { Ulex europaeus } \mathrm{L} .\end{array}$ & $\begin{array}{l}\text { Microwave hydrodiffusion and } \\
\text { gravity extraction (MHGE) }\end{array}$ & $\begin{array}{l}\text { MHGE allowed an efficient water } \\
\text { removal from the material, and could be } \\
\text { suitable for extraction of antioxidant } \\
\text { rich aromatic compounds }\end{array}$ & [107] \\
\hline Tomatoes & $\begin{array}{l}\text { Deep eutectic solvent-based } \\
\text { microwave-assisted dispersive } \\
\text { liquid-liquid microextraction } \\
\text { preconcentration of multiclass } \\
\text { pesticide residues in tomato } \\
\text { samples (DES-MWA-DLLME) }\end{array}$ & $\begin{array}{l}\text { DES-MWA-DLLME represented good } \\
\text { repeatability, } \\
\text { high (enrichment factors) EFs, low } \\
\text { (limit of detection) LODs }\end{array}$ & [108] \\
\hline
\end{tabular}

\section{Conclusions}

As natural bioactive compounds rich in antioxidants, therapeutic properties of betalain and phenolic compounds are numerous. Although they are sensitive to heat, $\mathrm{pH}$, light, etc., not only during processing but also throughout the storage, their presence in food wastes and residues even after processing is noteworthy as well. Currently, their practical usages in food industries, fortification, and supplementation of foods, cosmetics, and pharmaceuticals are thriving. Therefore, further thorough investigations for extraction of these valuable compounds via modern technologies, meantime maintaining their original properties as much as possible, are still needed to be explored. 
Most of MAE discussed in this review are operated in batch, although semi-continuous or continuous modes are also available. Since microwave irradiation encourages the direct interaction of vast electromagnetic waves and the target material, higher power ensures enough contact of the microwave with the matrix to expedite the isolation of the compounds trapped in the cell wall. Therefore, high temperature or power and short irradiation time is a beneficial combination for MAE of plant materials. Higher extraction time is not necessary once after the equilibrium state between the solvent and the matrix is reached since it can lead to the degradation of most bioactive compounds. All in all, if it is in proper use, microwave can be the best option for bioactive compounds extraction for the sake of simplicity as it can easily be set up or run by the home used microwave oven, high efficiency as the heating is built at the innermost part of the matrix and diffuses to the surrounding, saving energy as the operation can be completed in few minutes, and cleanliness as it is the only way of solvent free or lowest solvent used extraction.

Author Contributions: Conceptualization, M.M.Z.; methodology, M.M.Z.; software, M.M.Z., C.B.A.; resources, M.M.Z., C.B.A.; writing-original draft preparation, M.M.Z.; writing-review and editing, M.M.Z., C.B.A.; supervision, S.B. All authors have read and agreed to the published version of the manuscript.

Funding: This study was financially supported by the European Union and the European Social Fund (grant agreement no.EFOP-3.6.3-VEKOP-16-2017-00005), Tempus Public Foundation, under the Stipendium Hungaricum Scholarship Program.

Acknowledgments: We appreciate the Doctoral School of Food Science, Szent Istvan University for the support accomplishing this work as well as the European Union's Horizon 2020 research and innovation programme under the Marie Sklowdowska—Curie grant No: 765860 (AQUAlity).

Conflicts of Interest: The authors declare no conflict of interest.

\section{References}

1. Zaukuu, J.L.Z.; Bodor, Z.; Vitalis, F.; Zsom-Muha, V.; Kovacs, Z. Near infrared spectroscopy as a rapid method for detecting paprika powder adulteration with corn flour. Acta Period. Technol. 2019, 50, 346-352. [CrossRef]

2. Khan, M.I.; Giridhar, P. Plant betalains: Chemistry and biochemistry. Phytochemistry 2015, 117, 267-295. [CrossRef] [PubMed]

3. Choo, W.S. Betalains: Application in functional foods. In Bioactive Molecules in Food, Reference Series in Phytochemistry; Mérillon, J.-M., Ramawat, K.G., Eds.; Springer: Cham, Switzerland, 2019; pp. 1471-1498.

4. Slimen, I.B.; Najar, T.; Abderrabba, M. Chemical and antioxidant properties of betalains. J. Agric. Food Chem. 2017, 65, 675-689. [CrossRef] [PubMed]

5. Hussain, E.A.; Sadiq, Z.; Zia-Ul-Haq, M. Betalains: Biomolecular Aspects, 1st ed.; Springer International Publishing, AG: Cham, Switzerland, 2018; pp. 1-187.

6. Rodriguez-Amaya, D.B. Betalains. Encycl. Food Chem. 2019, 35-39. [CrossRef]

7. Maran, J.P.; Priya, B. Multivariate statistical analysis and optimization of ultrasound-assisted extraction of natural pigments from waste red beet stalks. J. Food Sci. Technol. 2016, 53, 792-799. [CrossRef] [PubMed]

8. Singh, A.; Ganesapillai, M.; Gnanasundaram, N. Optimizaton of extraction of betalain pigments from beta vulgaris peels by microwave pretreatment. In IOP Conference Series: Materials Science and Engineering, Proceedings of the 14th ICSET-2017, School of Advanced Sciences, VIT University, Vellore, India, 2-3 May 2017; IOP Publishing: Bristol, UK, 2017; Volume 263.

9. Zin, M.M.; Márki, E.; Bánvölgyi, S. Conventional extraction of betalain compounds from beetroot peels with aqueous ethanol solvent. Acta Aliment. 2020, 49, 163-169. [CrossRef]

10. Costa, A.P.D.; Hermes, V.S.; Rios, A.D.O.; Flores, S.H. Minimally processed beetroot waste as an alternative source to obtain functional ingredients. J. Food Sci. Technol. 2017, 54, 2050-2058. [CrossRef] [PubMed]

11. Vulić, J.J.; Ćebović, T.N.; Čanadanović, V.M.; Ćetković, G.S.; Djilas, S.M.; Čanadanović-Brunet, J.M.; Velićanski, A.S.; Cvetković, D.D.; Tumbas, V.T. Antiradical, antimicrobial and cytotoxic activities of commercial beetroot pomace. Food Funct. 2013, 4, 713-721. [CrossRef]

12. Bucur, L.; Ţarălungă, G.; Schroder, V. The betalains content and antioxidant capacity of red beet (Beta vulgaris L. subsp. vulgaris) root. Farmacia 2016, 64, 198-201. 
13. Székely, D.; Szalóki-Dorkó, L.; Stéger-Máté, M.; Szabó-Nótin, B.; Ivanics, J.; Monspart-Sényi, J. Distribution of antioxidant components in roots of different red beets (Beta vulgaris L.) cultivars. Acta Aliment. 2014, 43, 164-171. [CrossRef]

14. Bastos, E.L.; Gonçalves, L.C.P. Microwave-Assisted extraction of betalains. In Water Extraction of Bioactive Compounds: From Plants to Drug Development; González, H.D., Muñoz, M.J.G., Eds.; Elsevier: Amsterdam, The Netherlands, 2017; pp. 245-267.

15. Sawicki, T.; Baczek, N.; Wiczkowski, W. Betalain profile, content and antioxidant capacity of red beetroot dependent on the genotype and root part. J. Funct. Foods 2016, 27, 249-261. [CrossRef]

16. Gallo, M.; Ferracane, R.; Graziani, G.; Ritieni, A.; Fogliano, V. Microwave assisted extraction of phenolic compounds from four different spices. Molecules 2010, 15, 6365-6374. [CrossRef] [PubMed]

17. Martín, J.; Navas, M.J.; Jiménez-Moreno, A.M.; Asuero, A.G. Anthocyanin pigments: Importance, sample preparation and extraction. In Phenolic Compounds: Natural Sources, Importance and Applications; Soto-Hernández, M., Palma-Tenango, M., García-Mateos, R., Eds.; BoD—Books on Demand: Norderstedt, Germany, 2017; pp. 117-152.

18. Li, H.; Deng, Z.; Wu, T.; Liu, R.; Loewen, S.; Tsao, R. Microwave-assisted extraction of phenolics with maximal antioxidant activities in tomatoes. Food Chem. 2012, 130, 928-936. [CrossRef]

19. Proestos, C.; Komaitis, M. Application of microwave-assisted extraction to the fast extraction of plant phenolic compounds. LWT Food Sci. Technol. 2008, 41, 652-659. [CrossRef]

20. Yuan, Y.; Zhang, J.; Fan, J.; Clark, J.; Shen, P.; Li, Y.; Zhang, C. Microwave assisted extraction of phenolic compounds from four economic brown macroalgae species and evaluation of their antioxidant activities and inhibitory effects on $\alpha$-amylase, $\alpha$-glucosidase, pancreatic lipase and tyrosinase. Food Res. Int. 2018, 113, 288-297. [CrossRef]

21. Balasundram, N.; Sundram, K.; Samman, S. Phenolic compounds in plants and agri-industrial by-products: Antioxidant activity, occurrence, and potential uses. Food Chem. 2006, 99, 191-203. [CrossRef]

22. Rocchetti, G.; Blasi, F.; Montesano, D.; Ghisoni, S.; Marcotullio, M.C.; Sabatini, S.; Cossignani, L.; Lucini, L. Impact of conventional/non-conventional extraction methods on the untargeted phenolic profile of Moringa oleifera leaves. Food Res. Int. 2018, 115, 319-327. [CrossRef]

23. Seoane, P.R.; Flórez-Fernández, N.; Piñeiro, E.C.; González, H.D. Microwave-assisted water extraction. In Water Extraction of Bioactive Compounds: From Plants to Drug Development; González, H.D., Muñoz, M.J.G., Eds.; Elsevier: Amsterdam, The Netherlands, 2017; pp. 163-198.

24. Cardoso-Ugarte, G.A.; Sosa-Morales, M.E.; Ballard, T.; Liceaga, A.; San Martín-González, M.F. Microwave-Assisted extraction of betalains from red beet (Beta vulgaris). LWT Food Sci. Technol. 2014, 59, 276-282. [CrossRef]

25. Aberoumand, A.A. Review article on edible pigments properties and sources as natural biocolorants in foodstuff and food industry. World J. Dairy Food Sci. 2011, 6, 71-78. [CrossRef]

26. Renard, C. Extraction of bioactives from fruit and vegetables: State of the art and perspectives. LWT Food Sci. Technol. 2018, 93, 390-395. [CrossRef]

27. Delgado-Vargas, F.; Jiménez, A.R.; Paredes-López, O. Natural pigments: Carotenoids, anthocyanins, and betalains-Characteristics, biosynthesis, processing, and stability. Crit. Rev. Food Sci. Nutr. 2010, 40. [CrossRef]

28. Stintzing, F.C.; Carle, R. Functional properties of anthocyanins and betalains in plants, food, and in human nutrition. Trends Food Sci. Technol. 2004, 15, 19-38. [CrossRef]

29. Merhan, O. The biochemistry and antioxidant properties of carotenoids. In Carotenoids; Cvetkovic, D., Nikolic, G., Eds.; IntechOpen: London, UK, 2017; pp. 51-66.

30. Urnau, L.; Colet, R.; Soares, V.F.; Franceschi, E.; Valduga, E.; Steffens, C. Extraction of carotenoids from Xanthophyllomyces dendrorhous using ultrasound-assisted and chemical cell disruption methods. Can. J. Chem. Eng. 2018, 96, 1377-1381. [CrossRef]

31. Sperry, J.B.; Smith, A.B., III. Chemical synthesis of diverse phenolic compounds isolated from olive oils. Olives Olive Oil Health Dis. Prev. 2010, 1439-1464. [CrossRef]

32. Tanaka, Y.; Sasaki, N.; Ohmiya, A. Biosynthesis of plant pigments: Anthocyanins, betalains and carotenoids. Plant J. 2008, 54, 733-749. [CrossRef]

33. Strack, D.; Vogt, T.; Schliemann, W. Recent advances in betalain research. Phytochemistry 2003, 62, $247-269$. [CrossRef] 
34. Slavov, A.; Karagyozov, V.; Denev, P.; Kratchanova, M.; Kratchanov, C. Antioxidant activity of red beet juices obtained after microwave and thermal pretreatments. Czech J. Food Sci. 2013, 31, 139-147. [CrossRef]

35. Nieves, J.W. Alternative therapy through nutrients and nutraceuticals. In Osteoporosis, 4th ed.; Marcus, R., Feldman, D., Dempster, D.W., Luckey, M., Cauley, J.A., Eds.; Academic Press: Cambridge, MA, USA, 2013; pp. 1739-1749.

36. Shetty, M.J.; Geethalekshmi, P.R.; Mini, C. Natural pigments as potential food colourants: A Review. Trends Biosci. 2017, 10, 4057-4064.

37. Esquivel, P. Betalains. In Handbook on Natural Pigments in Food and Beverages: Industrial Applications for Improving Food Color; Carle, R., Schweiggert, R.M., Eds.; Elsevier Ltd.: Amsterdam, The Netherlands, 2016; pp. 81-99.

38. Miguel, M. Betalains in some species of the amaranthaceae family: A Review. Antioxidants 2018, 7, 53. [CrossRef]

39. Lee, E.J.; An, D.; Nguyen, C.T.T.; Patil, B.S.; Kim, J.; Yoo, K.S. Betalain and betaine composition of greenhouse-or field-produced beetroot (Beta vulgaris L.) and inhibition of HepG2 cell proliferation. J. Agric. Food Chem. 2014, 62, 1324-1331. [CrossRef]

40. Cai, Y.Z.; Sun, M.; Corke, H. Characterization and application of betalain pigments from plants of the Amaranthaceae. Trends Food Sci. Technol. 2005, 16, 370-376. [CrossRef]

41. Mikołajczyk-Bator, K.; Pawlak, S. The effect of thermal treatment on antioxidant capacity and pigment contents in separated betalain fractions. Acta Sci. Pol. Technol. Aliment. 2016, 15, 257-265. [CrossRef] [PubMed]

42. Gonçalves, L.C.P.; Di Genova, B.M.; Dörr, F.A.; Pinto, E.; Bastos, E.L. Effect of dielectric microwave heating on the color and antiradical capacity of betanin. J. Food Eng. 2013, 118, 49-55. [CrossRef]

43. Nemzer, B.; Pietrzkowski, Z.; Spórna, A.; Stalica, P.; Thresher, W.; Michałowski, T.; Wybraniec, S. Betalainic and nutritional profiles of pigment-enriched red beet root (Beta vulgaris L.) dried extracts. Food Chem. 2011, 127, 42-53. [CrossRef]

44. Zin, M.M.; Márki, E.; Bánvölgyi, S. Evaluation of reverse osmosis membranes in concentration of beetroot peel extract. Period. Polytech. Chem. Eng. 2020, 64, 340-348. [CrossRef]

45. Bazaria, B.; Kumar, P. Optimization of spray drying parameters for beetroot juice powder using response surface methodology (RSM). J. Saudi Soc. Agric. Sci. 2018, 17, 408-415. [CrossRef]

46. Junqueira-Goncalves, M.P.; Cardoso, L.P.; Pinto, M.S.; Pereira, R.M.; Soares, N.F.; Miltz, J. Irradiated beetroot extract as a colorant for cream cheese. Radiat. Phys. Chem. 2011, 80, 114-118. [CrossRef]

47. Sivakumar, V.J.; Anna, J.L.; Vijayeeswarri, J.; Swaminathan, G. Ultrasound assisted enhancement in natural dye extraction from beetroot for industrial applications and natural dyeing of leather. Ultrason. Sonochem. 2009, 16, 782-789. [CrossRef]

48. Delia, S.C.; Chávez, G.M.; Frank, M.L.M.; Araceli, S.G.P.; Irais, A.L.; Franco, A.A. Spray drying microencapsulation of betalain rich extracts from Escontria chiotilla and Stenocereus queretaroensis fruits using cactus mucilage. Food Chem. 2018, 272, 715-722. [CrossRef]

49. Otálora, M.C.; Carriazo, J.G.; Iturriaga, L.; Osorio, C.; Nazareno, M.A. Encapsulating betalains from Opuntia ficus-indica fruits by ionic gelation: Pigment chemical stability during storage of beads. Food Chem. 2016, 202, 373-382. [CrossRef]

50. Hidalgo, A.; Brandolini, A.; Čanadanović-Brunet, J.; Ćetković, G.; Šaponjac, V.T. Microencapsulates and extracts from red beetroot pomace modify antioxidant capacity, heat damage and colour of pseudocereals-enriched einkorn water biscuits. Food Chem. 2018, 268, 40-48. [CrossRef] [PubMed]

51. Swanson, B.G. Tannins, and polyphenols. In Encyclopedia of Food Sciences and Nutrition, 2nd ed.; Caballero, B., Ed.; Academic Press: Cambridge, MA, USA, 2003; pp. 5729-5733.

52. Rodríguez-Rojo, S.; Visentin, A.; Maestri, D.; Cocero, M.J. Assisted extraction of rosemary antioxidants with green solvents. J. Food Eng. 2012, 109, 98-103. [CrossRef]

53. Flórez, N.; Conde, E.; Domínguez, H. Microwave assisted water extraction of plant compounds. J. Chem. Technol. Biotechnol. 2015, 90, 590-607. [CrossRef]

54. Wang, L.; Qin, P.; Hu, Y. Study on the microwave-assisted extraction of polyphenols from tea. Front. Chem. Eng. China 2010, 4, 307-313. [CrossRef]

55. Vinatoru, M.; Mason, T.J.; Calinescu, I. Ultrasonically assisted extraction (UAE) and microwave assisted extraction (MAE) of functional compounds from plant materials. TrAC Trends Anal. Chem. 2017, 97, 159-178. [CrossRef] 
56. Chong, P.H.; Yusof, Y.A.; Aziz, M.G.; Mohd Nazli, N.; Chin, N.L.; Syed Muhammad, S.K. Evaluation of solvent extraction of Amaranth betacyanins using multivariate analysis. Int. Food Res. J. 2014, 21, 1569-1573.

57. López, N.; Puértolas, E.; Condón, S.; Raso, J.; Alvarez, I. Enhancement of the extraction of betanine from red beetroot by pulsed electric fields. J. Food Eng. 2009, 90, 60-66. [CrossRef]

58. Latorre, M.E.; Bonelli, P.R.; Rojas, A.M.; Gerschenson, L.N. Microwave inactivation of red beet (Beta vulgaris L. var. conditiva) peroxidase and polyphenoloxidase and the effect of radiation on vegetable tissue quality. J. Food Eng. 2012, 109, 676-684. [CrossRef]

59. Ohlsson, T.; Bengtsson, N. Minimal Processing Technologies in the Food Industry, 1st ed.; CRC Press: New York, NY, USA, 2002; pp. 4-29.

60. Casazza, A.A.; Aliakbarian, B.; Mantegna, S.; Cravotto, G.; Perego, P. Extraction of phenolics from Vitis vinifera wastes using non-conventional techniques. J. Food Eng. 2010, 100, 50-55. [CrossRef]

61. Gharekhani, M.; Ghorbani, M.; Rasoulnejad, N. Microwave-Assisted extraction of phenolic and flavonoid compounds from Eucalyptus camaldulensis Dehn leaves as compared with ultrasound-assisted extraction. Lat. Am. Appl. Res. 2012, 42, 305-310.

62. Hayat, K.; Hussain, S.; Abbas, S.; Farooq, U.; Ding, B.; Xia, S.; Jia, C.; Zhang, X.; Xia, W. Optimized microwave-assisted extraction of phenolic acids from citrus mandarin peels and evaluation of antioxidant activity In Vitro. Sep. Purif. Technol. 2009, 70, 63-70. [CrossRef]

63. Melgar, B.; Dias, M.I.; Barros, L.; Ferrerira, I.C.F.R.; Rodriguez-Lopez, A.D.; Garcia-Castello, E.M. Ultrasound and microwave assisted extraction of Opuntia fruit peels biocompounds: Optimization and comparison using RSM-CCD. Molecules 2019, 24, 3618. [CrossRef] [PubMed]

64. Rafiee, Z.; Jafari, S.M.; Alami, M.; Khomeiri, M. Microwave-Assisted extraction of phenolic compounds from olive leaves; a comparison with maceration. J. Anim. Plant Sci. 2011, 21, 738-745.

65. Kaderides, K.; Papaoikonomou, L.; Serafim, M.; Goula, A.M. Microwave-Assisted extraction of phenolics from pomegranate peels: Optimization, kinetics, and comparison with ultrasounds extraction. Chem. Eng. Process. 2019, 137, 1-11. [CrossRef]

66. Medina-Torres, N.; Ayora-Talavera, T.; Espinosa-Andrews, H.; Sánchez-Contreras, A.; Pacheco, N. Ultrasound assisted extraction for the recovery of phenolic compounds from vegetable sources. Agronomy 2017, 7, 47. [CrossRef]

67. Ballard, T.S.; Mallikarjunan, P.; Zhou, K.; O'Keefe, S. Microwave-Assisted extraction of phenolic antioxidant compounds from peanut skins. Food Chem. 2010, 120, 1185-1192. [CrossRef]

68. Jokić, S.; Cvjetko, M.; Božić, D.; Fabek, S.; Toth, N.; Vorkapić-Furač, J.; Redovniković, I.R. Optimisation of microwave-assisted extraction of phenolic compounds from broccoli and its antioxidant activity. Int. J. Food Sci. Technol. 2012, 47, 2613-2619. [CrossRef]

69. Pérez-Serradilla, J.A.; Luque de Castro, M.D. Microwave-Assisted extraction of phenolic compounds from wine lees and spray-drying of the extract. Food Chem. 2011, 124, 1652-1659. [CrossRef]

70. Pinela, J.; Prieto, M.A.; Carvalho, A.M.; Barreiro, M.F.; Oliveira, M.B.P.P.; Barros, L.; Ferreira, I.C.F.R. Microwave-Assisted extraction of phenolic acids and flavonoids and production of antioxidant ingredients from tomato: A nutraceutical-oriented optimization study. Sep. Purif. Technol. 2016, 164, 114-124. [CrossRef]

71. Song, J.; Li, D.; Liu, C.; Zhang, Y. Optimized microwave-assisted extraction of total phenolics (TP) from Ipomoea batatas leaves and its antioxidant activity. Innov. Food Sci. Emerg. Technol. 2011, 12, $282-287$. [CrossRef]

72. Thirugnanasambandham, K.; Sivakumar, V. Microwave assisted extraction process of betalain from dragon fruit and its antioxidant activities. J. Saudi Soc. Agric. Sci. 2017, 16, 41-48. [CrossRef]

73. Zhao, C.N.; Zhang, J.J.; Li, Y.; Meng, X.; Li, H.B. Microwave-Assisted extraction of phenolic compounds from melastoma sanguineum fruit: Optimization and identification. Molecules 2018, 23, 2498. [CrossRef] [PubMed]

74. Ferreres, F.; Grosso, C.; Gil-Izquierdo, A.; Valentão, P.; Mota, A.T.; Andrade, P.B. Optimization of the recovery of high-value compounds from pitaya fruit by-products using microwave-assisted extraction. Food Chem. 2017, 230, 463-474. [CrossRef]

75. Pollini, L.; Rocchi, R.; Cossignani, L.; Mañes, J.; Compagnone, D.; Blasi, F. Phenol profiling and nutraceutical potential of Lycium spp. leaf extracts obtained with ultrasound and microwave assisted techniques. Antioxidants 2019, 8, 260. [CrossRef] 
76. Inglett, G.E.; Rose, D.J.; Chen, D.; Stevenson, D.G.; Biswas, A. Phenolic content and antioxidant activity of extracts from whole buckwheat (Fagopyrum esculentum Möench) with or without microwave irradiation. Food Chem. 2010, 119, 1216-1219. [CrossRef]

77. Nazeri, M.A.; Zain, N.M. Effect of different operating parameters on extraction of active compounds from pitaya peel by microwave assisted extraction (MAE). J. Teknol. (Sci. Eng.) 2018, 80, 51-58. [CrossRef]

78. Simsek, M.; Sumnu, G.; Sahin, S. Microwave assisted extraction of phenolic compounds from sour cherry pomace. Sep. Sci. Technol. 2012, 47, 1248-1254. [CrossRef]

79. Shao, P.; He, J.; Sun, P.; Zhao, P. Analysis of conditions for microwave-assisted extraction of total water-soluble flavonoids from Perilla frutescens leaves. J. Food Sci. Technol. 2012, 49, 66-73. [CrossRef]

80. Ravichandran, K.; Saw, N.M.M.T.; Mohdaly, A.A.A.; Gabr, A.M.M.; Kastell, A.; Riedel, H.; Cai, Z.; Knorr, D.; Smetanska, I. Impact of processing of red beet on betalain content and antioxidant activity. Food Res. Int. 2013, 50, 670-675. [CrossRef]

81. Pedroza, M.A.; Amendola, D.; Maggi, L.; Zalacain, A.; De Faveri, D.M.; Spigno, G. Microwave-Assisted extraction of phenolic compounds from dried waste grape skins. Int. J. Food Eng. 2015, 11, 359-370. [CrossRef]

82. Abolhasani, A.; Barzegar, M.; Sahari, M.A. Effect of gamma irradiation on the extraction yield, antioxidant, and antityrosinase activities of pistachio green hull extract. Radiat. Phys. Chem. 2017, 144, 373-378. [CrossRef]

83. Da Silva, H.R.P.; da Silva, C.; Bolanho, B.C. Ultrasonic-Assisted extraction of betalains from red beet (Beta vulgaris L.). J. Food Process Eng. 2018, 41, 1-6. [CrossRef]

84. Laqui-Vilca, C.; Aguilar-Tuesta, S.; Mamani-Navarro, W.; Montaño-Bustamante, J.; Condezo-Hoyos, L. Ultrasound-Assisted optimal extraction and thermal stability of betalains from colored quinoa (Chenopodium quinoa Willd) hulls. Ind. Crop. Prod. 2018, 90, 60-66. [CrossRef]

85. Liu, B.; Ma, Y.; Liu, Y.; Yang, Z.; Zhang, L. Ultrasonic-Assisted extraction and antioxidant activity of flavonoids from Adinandra nitida leaves. Trop. J. Pharm. Res. 2013, 12, 1045-1051. [CrossRef]

86. Loginova, K.V.; Lebovka, N.I.; Vorobiev, E. Pulsed electric field assisted aqueous extraction of colorants from red beet. J. Food Eng. 2011, 106, 127-133. [CrossRef]

87. Nayak, C.A.; Chethana, S.; Rastogi, N.K.; Raghavarao, K.S.M.S. Enhanced mass transfer during solid-liquid extraction of gamma-irradiated red beetroot. Radiat. Phys. Chem. 2006, 75, 173-178. [CrossRef]

88. Ramli, N.S.; Ismail, P.; Rahmat, A. Influence of conventional and ultrasonic-assisted extraction on phenolic contents, betacyanin contents, and antioxidant capacity of red dragon fruit (Hylocereus polyrhizus). Sci. World J. 2014, 1-7. [CrossRef]

89. Zvitov, R.; Nussinovitch, A. Low DC electrification of gel-plant tissue "sandwiches" facilitates extraction and separation of substances from Beta vulgaris beetroots. Food Hydrocoll. 2005, 19, 997-1004. [CrossRef]

90. Wizi, J.; Wang, L.; Hou, X.; Tao, Y.; Ma, B.; Yang, Y. Ultrasound-Microwave assisted extraction of natural colorants from sorghum husk with different solvents. Ind. Crop. Prod. 2018, 120, 203-213. [CrossRef]

91. Destandau, E.; Michel, T.; Elfakir, C. Microwave-Assisted extraction. In Natural Product Extraction: Principles and Applications; Rostagno, M.A., Prado, J.M., Eds.; The Royal Society of Chemistry: London, UK, 2013; pp. 113-156.

92. Figura, L.O.; Teixeira, A.A. Food Physics: Physical Properties-Measurement and Applications; Springer: Berlin/Heidelberg, Germany, 2007; pp. 380-386.

93. Filly, A.; Fernandez, X.; Minuti, M.; Visinoni, F.; Cravotto, G.; Chemat, F. Solvent-Free microwave extraction of essential oil from aromatic herbs: From laboratory to pilot and industrial scale. Food Chem. 2014, 150, 193-198. [CrossRef] [PubMed]

94. Ryynänen, S. The electromagnetic properties of food materials: A review of the basic principles. J. Food Eng. 1995, 26, 409-429. [CrossRef]

95. Hu, B.; Wang, H.; He, L.; Li, Y.; Li, C.; Zhang, Z.; Liu, Y.; Zhou, K.; Zhang, Q.; Liu, A.; et al. A method for extracting oil from cherry seed by ultrasonic-microwaveassisted aqueous enzymatic process and evaluation of its quality. J. Chromatogr. A 2019, 1587, 50-60. [CrossRef] [PubMed]

96. Benmoussa, H.; Elfalleh, W.; He, S.; Romdhane, M.; Benhamou, A.; Chawech, R. Microwave hydrodiffusion and gravity for rapid extraction of essential oil from Tunisian cumin (Cuminum cyminum L.) seeds: Optimization by response surface methodology. Ind. Crop. Prod. 2018, 124, 633-642. [CrossRef]

97. Bagherian, H.; Ashtiani, F.Z.; Fouladitajar, A.; Mohtashamy, M. Comparisons between conventional, microwave- and ultrasound-assisted methods for extraction of pectin from grapefruit. Chem. Eng. Process. Process Intensif. 2011, 50, 1237-1243. [CrossRef] 
98. Moradi, S.; Fazlali, A.; Hamedi, H. Microwave-Assisted hydro-distillation of essential oil from rosemary: Comparison with traditional distillation. Avicenna J. Med. Biotechnol. 2018, 10, 22-28.

99. Benmoussa, H.; Farhat, A.; Romdhane, M.; Bouajila, J. Enhanced solvent-free microwave extraction of Foeniculum vulgare Mill. essential oil seeds using double walled reactor. Arab. J. Chem. 2019, 12, 3863-3870. [CrossRef]

100. Chen, Q.; Dong, W.; Wei, C.; Hu, R.; Long, Y. Combining integrated ultrasonic-microwave technique with ethanol to maximise extraction of green coffee oil from Arabica coffee beans. Ind. Crop. Prod. 2020, 151, 112405. [CrossRef]

101. Jiang, Y.; Bai, X.; Lang, S.; Zhao, Y.; Liu, C.; Yu, L. Optimization of ultrasonic-microwave assisted alkali extraction of arabinoxylan from the corn bran using response surface methodology. Int. J. Biol. Macromol. 2019, 128, 452-458. [CrossRef]

102. Chemat, F.; Perino-Issartier, S.; Petitcolas, E.; Fernandez, X. "In situ" extraction of essential oils by use of Dean-Stark glassware and a Vigreux column inside a microwave oven: A procedure for teaching green analytical chemistry. Anal. Bioanal. Chem. 2012, 404, 679-682. [CrossRef]

103. Mullapudi, V.B.K.; Chandrasekaran, K.; Venkateswarlu, G.; Karunasagar, D. Development of a simple and rapid microwave-assisted extraction method using very dilute solutions of perchloric acid and hydrogen peroxide for the multi-elemental analysis of food materials by ICP-OES: A green analytical method. Microchemical 2019, 146, 807-817. [CrossRef]

104. Gravador, R.S.; Harrison, S.M.; Monahan, F.J.; Gkarane, V.; Farmer, L.J.; Brunton, N.P. Validation of a rapid microwave-assisted extraction method and GC-FID quantification of total branched chain fatty acids in lamb subcutaneous adipose tissue. J. Food Sci. 2018, 1-6. [CrossRef] [PubMed]

105. Raikos, V.; McDonagh, A.; Ranawana, V.; Duthie, G. Processed beetroot (Beta vulgaris L.) as a natural antioxidant in mayonnaise: Effects on physical stability, texture and sensory attributes. Food Sci. Hum. Wellness 2016, 5, 191-198. [CrossRef]

106. Ma, C.H.; Liu, T.T.; Yang, L.; Zu, Y.G.; Chen, X.; Zhang, L.; Zhang, Y.; Zhao, C. Ionic liquid-based microwave-assisted extraction of essential oil and biphenyl cyclooctene lignans from Schisandra chinensis Baill fruits. J. Chromatogr. A 2011, 1218, 8573-8580. [CrossRef] [PubMed]

107. López-Hortas, L.; Conde, E.; Falqué, E.; Domínguez, H. Flowers of Ulex europaeus L.-Comparing two extraction techniques (MHG and distillation). C. R. Chim. 2016, 19, 718-725. [CrossRef]

108. Farajzadeh, M.A.; Sohrabi, S.H.; Mohebbi, A.; Mogaddam, M.R.A. Combination of a modified quick, easy, cheap, efficient, rugged, and safe extraction method with a deep eutectic solvent based microwave-assisted dispersive liquid-liquid microextraction: Application in extraction and preconcentration of multiclass pesticide residues in tomato samples. J. Sep. Sci. 2019, 42, 1273-1280. 